\title{
Covering rape: \\ How the media determine how we understand sexualised violence
}

Alessia Tranchese

\begin{abstract}
The focus of this paper is a corpus study of the representation of rape in the mainstream quality press in the UK and a discussion of the broader social implications of such representation. This paper uses corpus analysis tools to study the discourse that surrounds the terms rape and raped and their collocates in a corpus of four British quality newspapers and compares the findings of the corpus analysis with corpus-external data (e.g. statistics on rape crimes, government reports, rape myths) to determine whether (and to what extent) the images foregrounded by the press in the corpus echo such contextual information. On the basis of this comparison, I argue that the representation of rape in the corpus reflects and reinforces dominant stereotypical understandings of rape rooted in patriarchal conceptualisations of gender roles and sexualities and perpetuated by established professional practices in mainstream journalism.
\end{abstract}

\section{Keywords}

Rape, critical discourse analysis, corpus analysis, news discourse, violence against women

\section{Introduction}

The aim of this paper is to use corpus analysis tools (particularly collocation and concordance analysis) to deconstruct the discourse that surrounds rape in the British quality press through the analysis of the terms rape and raped and their collocates in a corpus of four British newspapers.

Rape is the only gender-based crime in which one of the 'weapons' is always a sexual act; in fact, it is often referred to as sexual violence. According to British law, 'a person (A) commits an offence if he intentionally penetrates the vagina, anus or mouth of another person (B) with his penis' and if 'B does not consent to the penetration'. ${ }^{1}$ In other words, according to the legal definition, forced penetration by someone's penis is the sexual act that characterises rape. However, this sexual act happens without mutual consent and, therefore, it is considered an instrument of control and humiliation rather than a way to satisfy sexual arousal. As Kitzinger and Thomas (1995:45) have put it, "this "sexual" is the mean to an end not the end in itself. Power is the desired element'. Therefore, in this paper, rape will not be referred to as sexual violence but as sexist violence (as suggested 
by Pharr 1991:2), sexualised violence, gender-based violence or violence against women (VAW), to draw a line between a consensual act (sex) and a hate crime (rape). Although such expressions can also refer more broadly to other forms of VAW, they offer the advantage of placing rape within a social context of patriarchy and misogyny (Meyers 1997:8), thus taking the attention away from the sexual act, while emphasising the context of power difference between men and women in which VAW takes place.

Rape is also one of the crimes with the lowest reporting, prosecution and conviction rates in the $\mathrm{UK} ;{ }^{2}$ the reasons why a reported case does not continue to prosecution and conviction are varied and they do not necessarily indicate that the crime did not happen. ${ }^{3}$ Therefore, as the outcome of legal action is not sufficient to distinguish between a rape that happened and one that did not happen, in this paper men who were accused of rape will be referred to as perpetrators, while women who experienced rape will be referred to as survivors (Kelly 1988) (unless they were killed in the attack). While these word choices may not always reflect the legal terminology and the legal status of the men who were accused - as the corpus does not contain only articles where a conviction took place - they allow to avoid those very lexical choices that, as shown in the analysis below, seem to emphasise disbelief towards survivors.

While the legal definition of rape in the UK is gendered in terms of who can perpetrate it (i.e. a person of male sex), it is not gender-specific in relation to who can be a victim of rape. In fact, both men and women can experience rape. However, this study only considers acts of aggression directed at women by men because, whilst it cannot be denied that the rape of men can also represent an expression of power (Javaid 2016), 'from a semiotic standpoint, women and men are different signs and therefore signify differently so that the brutalization of a woman by a man cannot mean the same thing as the brutalization of a man by another man' (Meyers 1997:8). The implication of this assumption is not that men and women are intrinsically different, but that notions of gender in society are premised on difference and that patriarchal society's belief in and normalisation of such differences should be considered when discussing (the representation of) gender-based violence, i.e. a form of violence in which women are abused because they are women (Pharr 1997; Sunderland 2004).

Finally, even though rape can be described in terms of sexual acts, it is not possible to circumscribe the experience of rape within the rigid boundaries of its restrictive (legal) definition. Each person who has experienced rape is likely to have their own definition. Nor can the press accurately capture the experience of rape; in fact, its representation is likely to be based on a limited set of images and ideas, particularly because representations are often pre-formed and conform to existing stereotypes (Sunderland 2004). However, these images are not produced in a vacuum and, it may be argued that, when used by the media, the repetition and the scale of distribution of such images have the potential to eventually shape perceptions and reinforce stereotypes on sexualised violence (Emmers-Sommer et al. 2006; Levenson and D'Amora 2007). 


\section{Rape myths, media and discourse}

Media texts are not produced in a social vacuum but in a space in which different interests and power relationships are at play (Fairclough, 1995) and inevitably influence the images construed and represented in such texts. For example, Van Zoonen (1994) argues that stories are selected on the basis of their newsworthiness (and consequent ability to generate profit) and of other considerations, such as availability and sustainability of sources. Several scholars (e.g. van Dijk 1988; Richardson 2007; Bednarek and Caple 2012) have also argued that institutional sources (such as the police or the government) have preferential access to the media because of their perceived credibility and because of their ability to provide a continuous flow of news material. In this production line, in which decision making is clearly influenced by political, economic and social power relations, the ability to be heard is not democratically distributed but is very much under institutional control. As Fairclough has put it (1995:40) 'in general it is those who already have other forms of economic, political or cultural power that have the best access to the media'. In this sense, media discourse is ideological, in that it is 'meaning in the service of power' (Thompson 1990:7) that constantly reaffirms patterns of sense-making that serve the interests of dominant groups. As an institution endowed with the power of both representing and shaping reality on a large scale (Fairclough 1989:35-39), mainstream media have the potential to normalise such sense-making patterns, thus upholding and reinforcing the hegemonic dominant structure of society, including dominant patriarchal ideologies of which VAW is an expression (Lombard and McMillan 2013).

Fundamental in patriarchal ideology is a binary distinction of gender roles, according to which biological sex determines which (sexual) behaviours are appropriate for men and which ones are appropriate for women (Richardson and Robinson 2007). In patriarchy, men are socialised to be sexually aggressive to certify their manhood, while women are expected to be sexually submissive (Franiuk et al. 2008). Consequently, men are expected to be the initiators, while women are supposed to be the gatekeepers in sexual encounters (Grauerholz 1994:41; Franiuk et al. 2008). In this scenario, there is only a limited number of roles, or subject positions, that are available to men and women: women can either be virgins (i.e. pure and uninterested in sex) or vamps (i.e. provocative, available or promiscuous - Benedict, 1992: 18; Wood, 1994: 22; O'Hara, 2012), while men who force sexual attention onto women are held to be real men (Wood 1994:23; Lombard 2015).

Previous studies on the representation of VAW in the press (Soothill and Walby 1991; Meyers 1997; Clark 1992; Benedict 1992; Mason and Monckton-Smith 2008; O'Hara 2012) have suggested that such roles can also be found in media representations of rape, often channelled into a limited number of rape myths. For example, women who experience rape are often represented in the press as innocent and vulnerable virgins attacked by men who are often portrayed as evil monsters and/or perverts (Benedict 1992; 
Mason and Monckton-Smith 2008; O'Hara 2012). Such myths are troubling because of the effects they can have on society (including the legal system) and on rape survivors (Benedict 1992; Franiuk et al. 2008; Levenson and D'Amora 2007; Emmers-Sommer et al. 2006). Moreover, one of the consequences of channelling male and female sexuality into pre-packaged categories is that gender-based violence can easily be accepted as something that men are naturally inclined to commit, as they are seen as being naturally sexually aggressive; women must, therefore, take measures to protect themselves. In other words, it could be argued that the reasons why VAW often remains unquestioned, as argued by Wood (1994), are rooted in the patriarchal ideology that is largely controlled by those in power and legitimises the acceptance of rigid gender roles; this ideology is epitomised by dominant discourses that 'create subject positions that encourage men to harass women sexually and women to tolerate abuse' (Wood 1994:23). Thus, dominant discursive practices that reproduce oppressive gender constructions and ideologies can give rise to conditions and subject positioning that legitimise, sustain and normalise sexist harassment. By positioning subjects and events, such practices have the capacity not only to conceptualise and define social issues, but also to define how these issues should be understood, talked about and which views and behaviours should be considered legitimate and appropriate. It is the intention of this study to explore whether such attitudes are reflected and/or challenged in the coverage of rape in a corpus of articles published in the British quality press. In this paper, the representation of sexualised violence is conceptualised as a social practice that is articulated by both the discoursal representation of rape and non-discoursal factors such as social relations, structures and people that produce and receive media texts (Fairclough 2003:25). Conceptualising the representation of sexist violence as a social practice involves deconstructing the way in which this experience is represented and how sense is made of it. It also means acknowledging that both meaning encoding and decoding may be fundamentally partisan and ideological, as well as linked to specific practices and settings (van Dijk 1985, 1988; Fairclough 1989, 1995).

\section{Methodology and Corpus Building}

This study proposes a systematic, corpus-based investigation of the discursive construction of rape in the press and an integration of said analysis with a discussion of the wider context in which such representations are produced and received. A framework combining the mainly qualitative approach of Critical Discourse Analysis (CDA Fairclough 1989, 1995) with quantitative, corpus-based techniques, is the one adopted in this paper as proposed, among others, by Baker et al. (2008). While CDA explores inequality and power relations and examines the 'social, political and intertextual contexts, which go beyond analysis of the language within texts' (Baker et al. 2008:27- 
30), a Corpus Linguistics approach can limit the bias of manual analysis and it can provide an overview of linguistic patterns present in a large number of texts (Wild et al. 2013).

The corpus used for this analysis (henceforth the RAPE corpus) was collected through the online newspapers database Nexis ${ }^{4}$ and the corpus analysis was carried out with the freeware corpus analysis toolkit AntConc. ${ }^{5}$ The following daily versions of four national British quality papers were considered: The Guardian, The Independent, The Times and The Daily Telegraph. The search terms used to query the newspapers were: rape* OR rapist* OR raping and the time-span taken into consideration is January $1^{\text {st }}$ - December $31^{\text {st }}, 2008^{6}$. The corpus includes 484 articles, for a total of 250,841 words.

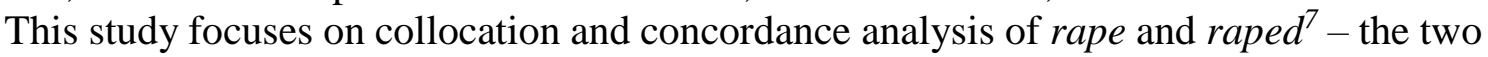
most frequent forms of the lemma $R A P E$ in the corpus. Sinclair's (1991:170) definition of collocation is adopted here, i.e. 'the occurrence of two or more words within a short space of each other in a text. The usual measure of proximity is a maximum of four words intervening ${ }^{8}$. Collocations were generated using the statistical measure T-score, which tends to show high frequency words that collocate with the search word. Unlike the measure of significance Mutual Information (MI), which tends to give high scores to low frequency words that are more unusual (Baker 2006:100ff), T-score foregrounds typical phraseological collocates, which can be particularly effective in revealing discoursive patterns.

Collocation analysis has been shown to be an effective method to support quantitative as well as qualitative discourse analytic investigations of texts as 'a way of understanding meanings and associations between words which are otherwise difficult to ascertain from a small-scale analysis of a single text' (Baker et al. 2008:96). Admittedly, collocations allow to detect 'the associations and connotations that words have and therefore the assumptions which they embody' (Stubbs 1996:172). Collocations can also contribute to the 'semantic analysis of a word' (Sinclair 1991:115-116), for example through the study of semantic prosody, i.e. the "consistent aura of meaning with which a form is imbued by its collocates' (Louw 1993:157). In this study, patterns of meaning association were investigated by comparing the RAPE corpus with the British National Corpus ${ }^{9}$ as well as with an ad-hoc corpus of news articles (henceforth General News corpus) which included a wide variety of text topics, i.e. not only articles concerning incidents of rape. While both the RAPE corpus and the General News corpus included articles taken from the same four national broadsheets and they both included several text types (i.e. editorials, comments, hard news, opinion pieces), the General News corpus consisted of all articles published by the four newspapers on the first day of each month in the same year and it amounted to a substantially larger corpus containing 5.057.173 words.

Finally, collocates of rape and raped were also analysed in their expanded co-text through concordance analysis, to infer contextual elements that would not be noticeable through collocation analysis only (Baker et al. 2008). As, in some cases, the number of concordance lines was particularly large, the analysis was conducted using a selection 
method advocated by Sinclair (1999). A group of 30 random ${ }^{10}$ lines were selected and patterns were noted; another group of 30 lines were selected for a second investigation and the new patterns were noted. This was done until further selections of 30 lines no longer showed new patterns. ${ }^{11}$

\section{Findings}

This section contains the findings of the collocation and concordance analyses of rape and raped, as well as an analysis of the semantic prosody and meaning association of some of the most frequent collocates of rape and raped.

\section{Rape}

Table 1 shows the top 20 lexical ${ }^{12}$ collocates $^{13}$ to the left and to the right of rape. ${ }^{14}$ 
Table 1: List of the 20 most frequent lexical collocates of rape

\begin{tabular}{rrrrl}
\hline Freq & Freq(L) & Freq(R) & Stat & Collocate \\
\hline $\mathbf{1 0 5}$ & 21 & 84 & 1.005 .395 & victims \\
\hline $\mathbf{8 9}$ & 21 & 68 & 924.577 & murder \\
\hline $\mathbf{5 4}$ & 9 & 45 & 719.459 & date \\
\hline $\mathbf{4 5}$ & 14 & 31 & 651.597 & victim \\
\hline $\mathbf{4 0}$ & 32 & 8 & 627.206 & attempted \\
\hline $\mathbf{4 6}$ & 30 & 16 & 619.631 & women \\
\hline $\mathbf{3 8}$ & 18 & 20 & 604.499 & conviction \\
\hline $\mathbf{3 6}$ & 18 & 18 & 595.509 & allegation \\
\hline $\mathbf{4 5}$ & 19 & 26 & 591.2 & police \\
\hline $\mathbf{3 9}$ & 10 & 29 & 569.871 & year \\
\hline $\mathbf{3 3}$ & 30 & 3 & 562.478 & alleged \\
\hline $\mathbf{3 3}$ & 4 & 29 & 559.714 & assault \\
\hline $\mathbf{3 0}$ & 11 & 19 & 536.302 & charges \\
\hline $\mathbf{2 8}$ & 15 & 13 & 521.875 & rate \\
\hline $\mathbf{3 1}$ & 6 & 25 & 515.898 & case \\
\hline $\mathbf{2 7}$ & 10 & 17 & 509.892 & allegations \\
\hline $\mathbf{2 7}$ & 25 & 2 & 503.873 & accused \\
\hline $\mathbf{2 9}$ & 9 & 20 & 503.043 & sexual \\
\hline $\mathbf{2 4}$ & 3 & 21 & 486.166 & crisis \\
\hline $\mathbf{2 2}$ & 5 & 17 & 464.117 & false \\
\hline & & & &
\end{tabular}

Table 1 contains six semantically related words, i.e. allegation(s), conviction, police, alleged, charges, accused, which belong to the domain of jurisprudence, as well as two terms - attempted and case - which also appear in the discussion of rape in the legal domain (e.g. he was also charged with an attempted rape; rape case to be reopened). Some collocates in Table 1 are part of fixed expressions such as: date-rape, sexual assault, rape crisis centre, conviction rate and false imprisonment and two of these expressions (i.e. conviction rate and false imprisonment) also belong to the legal domain. Particularly noteworthy is the presence of three forms of the same lemma, i.e. ALLEGE, with two nominal forms (allegation and allegations) and one verbal or adjectival form (alleged). In order to provide insight into why allegation and allegations are the most frequent collocates of rape in the RAPE corpus instead of, for example, accusation or complaint, this point is investigated further in the following. 
The Oxford English Dictionary ${ }^{15}$ defines allegation as 'an act of alleging something; an unproved claim or assertion. Also: an unfounded statement or accusation'. The investigation of the 30 strongest lexical collocates of the singular form allegation ${ }^{16}$ in the BNCweb shows that allegation co-occurs with terms such as: denied, withdraw, dismissed, unsubstantiated, refute, abandoned, false, untrue, deny. Moreover, in the $\mathrm{BNCweb}$, rape is also the only violent crime that collocates with allegation. Other crimes appear too, but they do not necessarily involve physical abuse (e.g. forgery, misconduct and negligence). Abuse also appears in the list but, in 3 out of 5 occurrences, it explicitly refers to sexual abuse. This seems to suggest a connection between allegation, a term whose semantic prosody is pervaded by denial, and crimes that involve sexual acts.

In the RAPE corpus, concordance lines of rape and its collocate allegation (in the singular form - Table 2) also reveal that rape allegation and allegation of rape often co-occur with terms that suggest falsity (e.g. denied, innocent of, stitch-up, totally untrue - in italics in Table 2). 
Table 2: Concordance lines of rape and the collocate allegation

\begin{tabular}{|c|c|c|c|}
\hline 1 & $\underline{\text { television presenter, }}$ made an allegation of & rape & against an unnamed presenter in her biograph \\
\hline 2 & former Blue Peter presenter has denied a new & rape & allegation made against $\mathrm{him}$, saying it is \\
\hline 3 & never resisted his advances and denied the & rape & allegation. \\
\hline 4 & women back to their hotel rooms following a & rape & allegation on the team's tour of New Zealand \\
\hline 5 & $>$ John Leslie faces & rape & allegation; HomeNews IN BRIEF *The former \\
\hline 6 & $>$ Leslie says & rape & allegation is a 'stitch-up' The former Blue \\
\hline 7 & appeal ruled yesterday. A delay in making a & rape & allegation is one of the factors most \\
\hline 8 & Evans insistent that he is innocent of the & rape & allegation, his case could be used to strength \\
\hline 9 & only eight days after being bailed over a & rape & allegation was jailed for life yesterday. \\
\hline 10 & murder eight days after being bailed over a & rape & allegation was jailed for life at the old \\
\hline 11 & No further action will be taken over a & rape & allegation made against the former Blue Peter \\
\hline 12 & Braithwaite had been bailed over a & rape & allegation seven days before killing Stacey \\
\hline 13 & after he was wrongly released on bail over a & rape & allegation, police claimed as he was jailed \\
\hline 14 & raithwaite had been held a week earlier over a & rape & allegation, but was freed to kill as police \\
\hline 15 & Peter presenter, will not face charges over a & rape & allegation made against him last month. A \\
\hline 16 & not worth pursuing." Some forces record any & rape & allegation as a crime as soon as a report is \\
\hline 17 & of a Filipino woman in a hotel room. The & rape & allegation has echoes of the 1995 gang rape \\
\hline 18 & Braithwaite having been bailed on the initial & rape & allegation. A police source said: "We felt \\
\hline 19 & to obscure property developer THE latest & rape & allegation against John Leslie came as the \\
\hline 20 & said: We are investigating an allegation of & rape & and indecent assault on a woman. The allegation \\
\hline 21 & CPS, said: We take any allegation of & rape & extremely seriously and all rape cases are \\
\hline 22 & $>$ Prime Minister denies allegation of & rape & GRENADINES The Prime Minister of a formee \\
\hline 23 & he described the latest allegation, of a & rape & in 1995, as totally untrue. He said: "I \\
\hline 24 & Leslie yesterday described an allegation of & rape & made against him as the "mother of all 'stitch \\
\hline 25 & as arrested last night over an allegation of & rape & - Mr Leslie, 43, attended a police station \\
\hline 26 & that the claims may include an allegation of & rape & , no formal complaint has been received. \\
\hline 27 & the police had not taken her allegation of & rape & seriously. Rape charges against Jagat Mawari \\
\hline 28 & her boyfriend $[\ldots]$ made an allegation of & rape & . So far the girl has made no formal complain \\
\hline 29 & teenager made an allegation of "sexual abuse/ & rape & '' to police and doctors at a hospital where \\
\hline 30 & Unit she had made a previous allegation of & rape & . Witnesses were not interviewed for months, \\
\hline 31 & Officers are investigating an allegation of & rape & and indecent assault on a woman dating from \\
\hline 32 & questioned by detectives over an allegation of & rape & and sexual assault in November 1995. \\
\hline 33 & 40 s was questioned over an allegation of & rape & and sexual assault in November 1995, an \\
\hline 34 & arrested after a woman made an allegation of & rape & at the team's Christmas party at the Great \\
\hline 35 & not taken her allegation of rape seriously. & Rape & charges against Jagat Mawari, 30 , were \\
\hline
\end{tabular}

Moreover, in the $R A P E$ corpus, the combinations rape allegation and allegations of rape often co-occur with the verbal form to bail over or noun phrase bail over (lines 9, 10, 12, 13, 18). The context of these concordance lines shows that they refer to the case of Christopher Braithwaite, in which rape allegations had been dismissed and the perpetrator had been released on bail. Thus, the evidence from the RAPE corpus seems to support the suggestion that the prosody of allegation is pervaded by denial, as suggested by Baker (2006:158): 'the nominalised allegation( $s$ ) form has a discourse prosody for denial which is not found with any of the other forms of ALLEGE'.

In the RAPE corpus, the pattern of association between sexualised violence and terms that suggest denial or scepticism is reinforced by the absence of accusation in the list of the most frequent collocates of rape. Admittedly, while accusation refers to a forceful assertion, allegation indicates an opinion or claim (that will need to be proved), ${ }^{17}$ thus 
emphasising its subjective nature. Rape (unlike murder) is also absent in the list of the most frequent collocates of accusation and accusations in the BNCweb.

The concordance lines in Table 2 also show a tendency towards impersonality through the backgrounding or deletion of agency (Henley et al. 1995). Grammatically, the term allegation is an example of nominalisation, i.e. the 'conversion of processes into nominals, which has the effect of backgrounding the process itself - its tense and modality are not indicated - and usually not specifying its participants, so that who is doing what to whom is left implicit' (Fairclough 1992:95). In the RAPE corpus, allegation appears in one of the following lexical combinations: allegation of rape or rape allegation, i.e. together with another nominalised process: rape. As it is the case with this type of transformation (Kress and Hodge 1979:10), both processes are transformed into things that can become the object of other processes such as facing, describing, investigating and including. In other words, actions are turned into objects or timeless and impersonal events, and what is specific is turned into general through an abstract nominal which is more similar to a state than a process (Kress and Hodge 1979:26-27). The effect of this transformation is to obscure the agents of such processes; both the person who raped and the person who alleged are deleted. Similarly, the person who was raped and the one against whom allegations were made are backgrounded or disappear altogether. This structure allows the focus to shift from the causer of the process and the person affected by it to the process/thing itself, thus weakening the connection between actors and process and obscuring relations of causality (making it difficult to recover who did what to whom). This way, rape becomes an attribute of allegation, rather than a (criminal) action committed by a person against another. The legal requirement in the UK to protect rape survivors' anonymity ${ }^{18}$ can partly explain the lack of attribution of rape complaints to a named individual (although the active voice - e.g. the woman alleged that - could still be used to make causality less ambiguous). However, this is not the case for perpetrators. ${ }^{19}$ In the RAPE corpus, the active voice is used when allegation appears in the phraseological unit to make an allegation in which the noun allegation is supported by the light verb to make. A light verb is 'a verb with little or no semantic content of its own which combines with a (usually indefinite) direct object noun [...] which itself expresses a verbal meaning' (Trask 1993:160). In this case, an event (to allege) is transformed into a thing and, more precisely, into the object of a verb that does not contribute to the semantic content of the expression. In other words, had to make an allegation been replaced by to allege, there would have been theoretically no alteration in terms of content. However, light verbs can contribute to the meaning of an expression in a subtler way. In this instance, it may be argued that the selection of to make an allegation of rape over to allege that creates more distance between the person who makes the allegation and the allegation itself, by making it more factual and less subjective (arguably, it would be harder to dispute the statement she made an allegation of rape than she alleged that she had been raped). In some cases, this distance is further exacerbated by a passive or progressive form (lines 2 and 7, Table 
2) that further backgrounds or deletes the agent/sayer. It may be argued that the lack of direct attribution of rape and allegation, together with the vagueness of nominalised processes and the weakening of the relationship between sayer and process through light verbs create a sense of impersonality and distance in the construction of the incident, because both survivor and attacker are not represented as directly involved in the process. The analysis of the concordance lines of rape and the plural form allegations (Table 3) shows similar patterns of denial (e.g. fabricated, dismissed, denied, cleared, false, not taken seriously ${ }^{20}$ - in italics in Table 3) and impersonality (e.g. line 15 where allegations of rape are something in which one is caught up in).

\section{Table 3: Concordance lines of rape and its collocate allegations}

\begin{tabular}{|c|c|c|c|}
\hline 1 & $>$ Evans & rape & allegations Perhaps some good will come of \\
\hline 2 & $>$ 'Accused' face & rape & allegations from police seventy-two hours \\
\hline 3 & that Kent Police took all sexual assault and & rape & allegations seriously and said that its \\
\hline 4 & to RFU The four plavers at the centre of & rape & allegations on England's tour to New Zealand \\
\hline 5 & two squad members who were at the centre of & rape & allegations on last month's tour to New Zealand \\
\hline 6 & four England rugby players at the centre of & rape & allegations formally refused yesterday to $\mathrm{sp}$ \\
\hline 7 & $>$ Footballer cleared of & rape & allegations (Photograph) - MANCHESTER \\
\hline 8 & their clear-up statistics the number of & rape & allegations recorded as crimes by police has \\
\hline 9 & them the four players at the centre of the & rape & allegations that so undermined the final wee \\
\hline 10 & argued about Braithwaite's arrest over the & rape & allegations. "This defendant . . carried \\
\hline 11 & have been trying to raise the proportion of & rape & allegations that end in conviction, which \\
\hline 12 & trial and appeal courts is regrettably of & rape & allegations which prove to be quite false. $\mathrm{E}$ \\
\hline 13 & The Crown Prosecution Service takes & rape & allegations very seriously and in the light \\
\hline 14 & led herself because police had not taken the & rape & allegations seriously, an accusation that $\mathrm{Ha}$ \\
\hline 15 & who found themselves caught up in & rape & allegations during the tour to New Zealand \\
\hline 16 & crown court that some women fabricated & rape & allegations for their own purposes. The app \\
\hline 17 & career ended in 2002 amid allegations of & rape & and sexual assault, expressed bitterness \\
\hline 18 & that the four players denied allegations of & rape & and sexual assault and had the support of \\
\hline 19 & denied the allegations of rape, attempted & rape & and assault by penetration but admitted the \\
\hline 20 & London, initially denied the allegations of & rape & , attempted rape and assault by penetration $b$ \\
\hline 21 & by the judge who dismissed allegations of & rape & brought by a 21-year-old Aberystwyth student \\
\hline 22 & the damage done when allegations of & rape & were not taken seriously enough. Braithwaite \\
\hline 23 & is life imprisonment. The allegations of & rape & , which carry a maximum sentence of 15 years \\
\hline 24 & conviction rate resulting from allegations of & rape & which are recorded by police forces 47,000 \\
\hline 25 & women to continue to report allegations of & rape & , while conceding that the authorities are st \\
\hline
\end{tabular}

Further inspection of the concordance lines shows that, when the perpetrator is not obscured (underlined in Table 2 and 3), he is often a celebrity or a politician (referred to by their name, title or profession). Some of these cases are immediately identifiable from the co-text of the node word in Tables 3 and 4: a Prime Minister, a football player (Jonny Evans), four members of a UK rugby team and a TV presenter (John Leslie). In some cases, though, they are not mentioned in the co-text; expanding the co-text (sample shown below, excerpts 1 and 2) revealed the same pattern in other lines too: 
1. [John] Leslie says rape allegation is a 'stitch-up'. [...] Scotland Yard confirmed a man in his 40s was questioned by detectives over an allegation of rape and sexual assault in November 1995. He has been bailed to a date in August. (line 32, Table 2)

2. A far more stringent code of conduct will be imposed on England rugby union players after a judge announced yesterday that he had fined two squad members who were at the centre of rape allegations on last month's tour to New Zealand. (line 5, Table 3)

The association found between allegation(s) of rape and cases that involve public figures is not as prominent in the concordance lines of alleged, which, unlike allegation $(s)$, does not have a prosody of denial, as suggested by Baker (2006) and as confirmed by the analysis of the concordance lines of alleged (Table 4) in the RAPE corpus (where the only verb that explicitly expresses denial is denied, line 28). ${ }^{21}$ The wider context of the concordance lines of the adjectival ${ }^{22}$ form of ALLEGE revealed that this was only used in relation to rapes committed by public figures 6 times out of $33 .{ }^{23}$ 
Table 4: Concordance lines of rape and its collocate alleged

\begin{tabular}{|c|c|c|c|}
\hline 1 & and bailed in connection with an alleged & rape & at Manchester United's Christmas party, \\
\hline 2 & centre-back arrested following an alleged & rape & at the old Trafford plavers' Christmas party \\
\hline 3 & Evans will not face charges over an alleged & rape & at the team's Christmas party, Greater Manchester \\
\hline 4 & assaulted. A delay in reporting an alleged & rape & is often seized on by the defence as evidence \\
\hline 5 & trial judges can tell jurors that an alleged & rape & victim could have delayed making a complaint \\
\hline 6 & results from scientific tests. An alleged & rape & was committed by a criminal who would have \\
\hline 7 & Japan. It followed other incidents of alleged & rape & , trespassing and drink driving. In an attempt \\
\hline 8 & Evans will not be prosecuted over alleged & rape & The Manchester United defender Jonny Evans \\
\hline 9 & has been compounded by a second alleged & rape & , of a Philippines-born woman by a US service \\
\hline 10 & discouraged her from reporting the alleged & rape & and pressured her into signing a false state \\
\hline 11 & Bush, was later charged over the alleged & rape & , and another series of rapes in 2005 involving \\
\hline 12 & , it was disclosed yesterday. The alleged & rape & is one of six sexual offences allegedly. \\
\hline 13 & other sexual activity, including the alleged & rape & of a four-year-old boy. Social services and \\
\hline 14 & all week to speak to them about the alleged & rape & of a teenage woman in a waterfront hotel room \\
\hline 15 & owing the arrest of a marine for the alleged & rape & of a 14-year-old girl on the island of Okinawa \\
\hline 16 & another is being questioned about the alleged & rape & of a Filipino woman in a hotel room. The \\
\hline 17 & owing the arrest of a marine for the alleged & rape & of a 14-year-old girl on the island of Okinawa \\
\hline 18 & "deep regret'' yesterday at the alleged & rape & of a 14-year-old Japanese girl by an America \\
\hline 19 & at four plavers were involved in the alleged & rape & of an 18-year-old girl in a hotel room. The \\
\hline 20 & minister, Yasuo Fukuda, called the alleged & rape & "unforgivable" and Shigeru Ishiba, the defence \\
\hline 21 & of 100,000 rupees (Âf 1,300 ) to the alleged & rape & victim for her bravery in coming forward to \\
\hline 22 & New Zealand paper reported that the alleged & rape & victim sought hospital treatment after her \\
\hline 23 & English ban on prosecutors talking to alleged & rape & victims, unknown elsewhere, is expected to \\
\hline 24 & > America's priority Two alleged & rape & cases involving a US marine and a soldier in \\
\hline 25 & hristopher Baithwaite, accused of murder and & rape & . He is alleged to have cut the throat of a \\
\hline 26 & won't convict in some cases of alleged date & rape & - because it might simply be impossible \\
\hline 27 & $\mathrm{~s}$ to suggest that some cases of alleged date & rape & should not end up in court. Dame Helen \\
\hline 28 & the night of the alleged attack but denied & rape & - The case against him was dropped after \\
\hline 29 & subjected to extreme violence, including & rape & , while others have alleged they were used to \\
\hline 30 & a house near Bristol and two counts of & rape & following the alleged attacks on the teenage \\
\hline 31 & Cab driver on trial for alleged passenger & rape & A taxi driver known for his "party cab", \\
\hline 32 & another trial for their alleged role in the & rape & and murder of three other women, including \\
\hline 33 & The CPS said the alleged victim of the & rape & had not made a full statement at the point \\
\hline
\end{tabular}

As in the case of allegation(s), alleged also tends to co-occur with nominalised forms of processes such as rape and attack(s); however, it may be argued that, as an adjective, alleged qualifies the crime rather than the relationship between one's word (the survivor's) and another's (the perpetrator's). Arguably, while alleged casts doubt on the truthfulness of the event, the noun phrase allegation(s) of rape/rape allegation(s) discredits the claim (rape is the modifier rather than the head in the noun phrase), which can then be refuted.

Two other frequent collocates of rape in the RAPE corpus (Table 1) are victims and victim. As shown in Table 5, both tend to co-occur in the expression rape victim(s) and $\operatorname{victim}(s)$ of rape. 
Table 5: 30 randomly selected concordance lines of rape and its collocates victim and victims

\begin{tabular}{|c|c|c|c|}
\hline 1. & level of award to a victim of & rape & due to alcohol consumption. "This stance \\
\hline 2 & information about the psychological effects of & rape & on the victim. But, given the scale \\
\hline 3 & rigour. It is hardly surprising that many & rape & victims have so lost confidence in the \\
\hline 4 & and a third of Britons believe a & rape & victim is largely responsible for an attack \\
\hline 5 & a justified furore over the revelation that & rape & victims have had their compensation cut by \\
\hline 6 & work together from the outset to build & rape & cases, and support victims. But none of \\
\hline 7 & this week revealed poor treatment some & rape & victims receive from the justice system, incl \\
\hline 8 & 11 in 2005 for Amnesty highlighted the prejudices & rape & victims still face if they do not \\
\hline 9 & of Aids-related illnesses every week - that & rape & victims who can afford them are given \\
\hline 10 & judges can tell jurors that an alleged & rape & victim could have delayed making a complaint \\
\hline 11 & $>$ Justice for & rape & victims is a postcode lottery victims \\
\hline 12 & matters as fundamental as rape. It treated 14 & rape & victims in one year abominably. It is \\
\hline 13 & unacceptable that the standard of service & rape & victims receive is dependent on where they \\
\hline 14 & York for the way it works with & rape & victims from the outset to build cases. " \\
\hline 15 & can only lead many more victims of & rape & to hesitate before reporting an attack. Why \\
\hline 16 & consumption may cost them compensation & rape & victims seeking compensation are having their \\
\hline 17 & $>$ & rape & victim escaped by writing message on her \\
\hline 18 & caused anger by referring to a teenage & rape & victim's photographs on the social networking \\
\hline 19 & $>$ & rape & victims failed by lack of funds, say \\
\hline 20 & an unforgiving light on the prejudices that & rape & victims suffer. But that struggle has taken \\
\hline 21 & to the injury". In the past year 14 & rape & victims - $1 \%$ of rape-related applications - w \\
\hline 22 & credibility of the victim first; why is & rape & a priority in some forces but not \\
\hline 23 & would a government minister ever attack a & rape & victim today? When she dares to suggest \\
\hline 24 & $>$ & rape & victim tells of night she was attacked \\
\hline 25 & level of award to a victim of & rape & due to alcohol consumption. It is never \\
\hline 26 & that one in four people believed that & rape & victims were partially responsible for their \\
\hline 27 & Jill Saward, one of the first & rape & victims in Britain to talk publicly about \\
\hline 28 & and should not apply to victims of & rape &.$"$ \\
\hline 29 & the low conviction rate by encouraging more & rape & victims to come forward and increasing the \\
\hline 30 & and convulsions for days. Unlike many foreign & rape & victims in India, the freelance journalist st \\
\hline
\end{tabular}

Here the violent action is nominalised too and, in the case of rape victim(s), it is presented as an attribute of the person affected by it, not an action of violence perpetrated against her. Similarly, victim(s) of rape obscures agency since the crime - not the person who committed it - is presented as the victimiser. It may be argued that the use of rape to preor post-modify victim( $(s)$ backgrounds or deletes the perpetrator, while the victimhood of the person who was harmed is foregrounded. Additionally, it could be speculated that the nominal form presents victimhood as a status (or identity) that is fixed in time rather than as the temporary result of an action. The frequency of such expressions may signal the reproduction of the language used by the judicial system to refer to women who experienced rape; in fact, this language is likely to be reproduced in the mainstream press due to its tendency to rely on a limited number of sources (van Dijk 1991; Richardson 2007).

While the list of collocates of rape (Table 1) contains three terms that refer to survivors (victim, victims and women), it also reveals the absence of nouns that categorise perpetrators (e.g. rapist, attacker, aggressor, man). This absence may indicate an attempt of the press to avoid terms that imply guilt if no conviction has taken place and/or a 
preference for other ways to refer him/them, such as his/their first and/or second name(s); however, the frequent obscuration of the perpetrator found in the concordances analysed so far (and in the following sections) suggests that this is not often the case. Moreover, unlike alleged victims of rape, which is a commonly used in the corpus (Table 4 and 5), expressions such as alleged rape perpetrator/perpetrator of rape, which could also be considered cautious alternatives, are not used in the RAPE corpus. Conversely, one of the ways that the press uses to talk about perpetrators is accused of rape (accused is one of the top 20 collocates of rape and it occurs almost exclusively in the passive or participle clause accused of rape). It could be argued that, by referring to a perpetrator as someone who is accused of rape, the emphasis is placed onto an action that was carried out against him (i.e. accusation of rape) rather than onto his status as suspect; admittedly, unlike the noun perpetrator or rapist (and rape victim), the participle forms do not assign a given or fixed status, but they indicate a flexible condition. A search for the term perpetrator (not as a collocate of rape) in the RAPE corpus showed that, unlike victim(s), it almost always refers to an abstract entity or concept rather than a specific person/people (e.g. The Home Office has also drawn up a Domestic Violence National Action Plan to bring more perpetrators to justice). While both victim(s) and perpetrator(s) are terms that can be applied to any crime, in the RAPE corpus, victim is the only one that is disambiguated, with rape and victim strongly associated in a fixed expression that arguably refers to an existing, established concept or identity; perpetrator, on the other hand, is left unspecified. Finally, it must be noted that the frequent use of victim(s) and woman may also be a consequence of the fact that the press is not allowed to disclose their identity. However, the choice to refer to them as victims rather than survivors, for example, would seem to confirm the hypothesis that the press represented in the RAPE corpus adheres to the institutional language used to describe rape and not to the one advocated by activists against gender-based violence (Kelly 1988).

The remaining collocates of rape in Table 1 are two terms that belong to the semantic group of crimes, i.e. murder and assault. The former occurs in most cases (53/89) in rape and murder, while the latter occurs mostly (30/32) in rape and sexual assault or rape and indecent assault. On the basis of this initial observation, it appears that rape crimes are often associated with other, particularly violent, crimes. This hypothesis was further explored through the analysis of the most frequent collocates of the second-most frequent form of the lemma RAPE in the corpus, i.e. raped (Table 6).

\section{Raped}

Table 6 shows the top 20 lexical collocates to the left and to the right of raped. ${ }^{24}$ 
Table 6: List of the 20 most frequent lexical collocates of raped

\begin{tabular}{|c|c|c|c|c|}
\hline Freq & Freq (L) & Freq (R) & stat & Collocate \\
\hline 51 & 4 & 47 & 7.11227 & murdered \\
\hline 44 & 30 & 14 & 6.5242 & woman \\
\hline 34 & 19 & 15 & 5.67642 & old \\
\hline 31 & 16 & 15 & 5.47718 & girl \\
\hline 31 & 14 & 17 & 5.3392 & year \\
\hline 31 & 21 & 10 & 5.30148 & women \\
\hline 23 & 17 & 6 & 4.64575 & man \\
\hline 21 & 16 & 5 & 4.55868 & repeatedly \\
\hline 17 & 0 & 17 & 4.11092 & strangled \\
\hline 14 & 14 & 0 & 3.69896 & gang \\
\hline 14 & 2 & 12 & 3.6769 & killed \\
\hline 14 & 2 & 12 & 3.67306 & times \\
\hline 13 & 6 & 7 & 3.58912 & schoolgirl \\
\hline 13 & 11 & 2 & 3.55577 & teenager \\
\hline 12 & 8 & 4 & 3.36876 & girls \\
\hline 13 & 4 & 9 & 3.33573 & years \\
\hline 12 & 3 & 9 & 3.32006 & men \\
\hline 11 & 5 & 6 & 3.29173 & beaten \\
\hline 10 & 10 & 0 & 3.14355 & abducted \\
\hline 10 & 6 & 4 & 3.11857 & student \\
\hline
\end{tabular}

The most frequent lexical collocate of raped is murdered; additionally, strangled, killed, beaten and abducted are other top collocates of raped that belong to the semantic field of violent crimes. A concordance analysis of raped was carried out to investigate this pattern more closely. Table 7 contains a list of 30 randomly selected concordance lines and it shows that rape is often accompanied by other crimes (in lists of two, mostly in the structure: *some_crime* and rape or rape and *some_crime*), particularly those that can cause bodily harm or death. In fact, Table 7 (in bold and underlined) shows that raped also co-occurs with attacked, stabbed, assaulted, battered, drugged, shot). 
Table 7: 30 randomly selected concordance lines of raped

\begin{tabular}{|c|c|c|c|}
\hline 1 & $>$ 'Taxi' woman & raped & A 26-year-old woman was raped by the driver \\
\hline 2 & open prisons after the case of an inmate who & raped & a 16-year-old girl while he was on the run. \\
\hline 3 & village. As she travelled to Rutshuru she was & raped & again, this time by Rwandan Hutu extremists \\
\hline 4 & to try to trace the relatives of a man who & raped & and murdered a schoolgirl in 1946. The \\
\hline 5 & expressed anger that the "evil stranger" who & raped & and murdered their "darling little girl" like \\
\hline 6 & 9, but her call was disconnected and she was & raped & and murdered, a court heard yesterday. \\
\hline 7 & scores of opposition supporters have been & raped & and $\underline{\text { murdered, }}$ and hopes of democratic \\
\hline 8 & DNA tests, it was clear that she had been & raped & and murdered. On Monday March 17 Hannah \\
\hline 9 & as a cover-up and that her daughter had been & raped & and murdered. The naked body of 15-year-old \\
\hline 10 & examination, which revealed that she had been & raped & and murdered. A barman and an alleged local \\
\hline 11 & the father of Caroline Saison, 18, who was & raped & and strangled in 2000 , said of Fourniret: \\
\hline 12 & $>$ Teenager ' & raped & as she lay dead or dying ' * Chef denies \\
\hline 13 & at several bars. Miss McCormick was later & raped & by a man she could only describe as being \\
\hline 14 & how she was knocked unconscious and & raped & by a man who climbed in through the open \\
\hline 15 & 86 , when she was 21 , Saward was attacked and & raped & by two men in her home - her father's \\
\hline 16 & her new home and waited for her. Then he & raped & her again, saying that "it was to teach me a \\
\hline 17 & 37, a pub chef, stabbed her seven times and & raped & her as she was dead or dying. But he said he \\
\hline 18 & alleging that $M r$ Gonsalves assaulted and & raped & her at his home on January 3. Lawyers in St \\
\hline 19 & using a knife. In May that year, he battered and & raped & a 22-year-old mother whom he ambushed as \\
\hline 20 & home in Southampton on 14 March 2003. He & raped & her several times in his Ford Transit van be \\
\hline 21 & his way in, pushed her on to the bed and & raped & her with such brutality that she passed out \\
\hline 22 & they have murdered my husband. They have & raped & me so many times. I do not know who is aliv \\
\hline 23 & $>$ Freed teenager & raped & mother-to-be A TEENAGER beat and raped a \\
\hline 24 & threw herself off a bridge after she was & raped & on a night out with friends, an inquest was \\
\hline 25 & by suggesting that women who are date- & raped & should not expect to take those who have \\
\hline 26 & miles away, a 14-year-old girl was allegedly & raped & twice. Harkin appeared before magistrates \\
\hline 27 & the offences were committed." Hanson, 65, & raped & two of his victims when they were aged 11 an \\
\hline 28 & about allegations that he drugged and & raped & women passengers. His arrest was described \\
\hline 29 & way off the path. The schoolgirl had been & raped & , battered about the head and shot twice at \\
\hline 30 & services in place for women who have been & raped & . Well, no. The women's movement of the 70 s \\
\hline
\end{tabular}

In order to understand whether the association between two or more crimes was a specific pattern of rape discourse or whether it was a common way of talking about crime in the four broadsheets, a list of the crimes ${ }^{25}$ associated with rape in the RAPE corpus was extracted through collocation analysis (Table 8); these same crimes were then retrieved in the General News corpus to explore whether they also tended to co-occur with other crimes $^{26}$ (Table 9). 
Table 8: List of crimes following or preceding rape and or and rape in the RAPE corpus

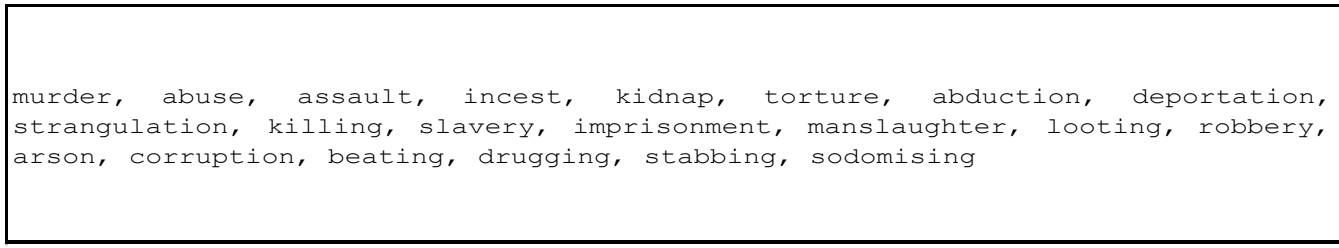


Table 9: List of crimes collocating with rape and crimes collocating with them (in the General News corpus)

\begin{tabular}{|ll|}
\hline CRIMES & COLLOCATES \\
\hline Abduction & killing, murder \\
\hline Abuse & $\begin{array}{l}\text { kidnap, harassment, mistreatment, murder, neglect, rape, } \\
\text { stalking, torture, trafficking }\end{array}$ \\
\hline Arson & - \\
\hline Assault & affray, murder \\
\hline Beating & abduction, killing, murder, pounding, rape, strangulation \\
\hline Corruption & bribery, fraud, rape, terrorism \\
\hline Deportation & - \\
\hline Drugging & smuggling, trafficking \\
\hline Imprisonment & assault, killing, rape, theft, torture \\
\hline Incest & coercion, rape \\
\hline Kidnap & $\begin{array}{l}\text { decapitation, extortion, murder, robbery, shooting, } \\
\text { stealing }\end{array}$ \\
\hline Killing & beating, rape, shooting, stabbing, torture \\
\hline Looting & burning, rape \\
\hline Manslaughter & sex-offence \\
\hline Murder & $\begin{array}{l}\text { abduction, abuse, ambush, assault, beating, espionage, } \\
\text { hijack, kidnap, rape, robbery, torture }\end{array}$ \\
\hline Robbery & burglary, kidnap, murder \\
\hline Slavery & tyranny \\
\hline Sodomising & - \\
\hline Stabbing & beating, rape, torture \\
\hline Strangulation & $\begin{array}{l}\text { beating, imprisonment, killing, maiming, murder, } \\
\text { mutilation, rape, strangulation }\end{array}$ \\
\hline Torture & \\
\hline
\end{tabular}

Table 9 shows that associating two or more crimes is common in the General News corpus. Even non-violent crimes like robbery, looting and corruption are associated with violent crimes like murder, kidnap and rape. This emphasis on violence is in line with 
the assumption that negativity plays a prominent role as news value (van Dijk 1988:99; Bednarek and Caple 2012; Potts et al. 2015). It may be argued that, in the case of rape too, particularly gruesome incidents would be considered more newsworthy and, therefore, receive extensive coverage.

Together with the propensity of raped to co-occur with violent crimes, Table 6 also shows that raped often co-occurs with repeatedly and times in the RAPE corpus. Closer observation reveals that these refer to multiple rapes (times, for example, is used to express how many times a man raped a woman). Moreover, raped often appears in the expression gang-raped. Both serial and gang rapes could be considered particularly ferocious forms of rape that emphasise physical violence. Similar patterns (emphasis on severe physical harm, death and multiple assaults) can be observed in several concordance lines in Table 7 (in bold). This was further investigated through a concordance analysis of another group of 30 randomly selected collocates (Table 10).

Table 10: 30 randomly selected concordance lines of raped

\begin{tabular}{|c|c|c|c|}
\hline 1 & GQ magazine, she said she & raped & a "couple of times". How would the harsh \\
\hline 2 & Roman Catholic nun who says that & raped & and paraded half-naked through the streets $b$ \\
\hline 3 & last week, a schoolgirl & raped & and then had drain-cleaning fluid poured on \\
\hline 4 & British woman has described how she & raped & at gunpoint after her husband was kicked \\
\hline 5 & had been gagged and & raped & at knifepoint at her home in Plumstead, a \\
\hline 6 & She was taunted, hit, threatened and orally & raped & by an ever-growing crowd of teenagers \\
\hline 7 & Jill Saward was 21 when she & raped & by burglars who broke into her family home \\
\hline 8 & they shot them too. Then the woman & raped & by five men. One of her attackers nearly des \\
\hline 9 & was held prisoner in the same cell. She & raped & by her father every three days on average an \\
\hline 10 & had been repeatedly & raped & by her stepfather was told she must bring he \\
\hline 11 & filled with women who & raped & by the militias and shot in the vagina. The \\
\hline 12 & identification The daughters who & raped & by their father, and their seven surviving \\
\hline 13 & policewoman, Gail Cox, that she & raped & by two brothers, Randy and Shawn Christian. \\
\hline 14 & journalism student from London & raped & in Calais. The woman was reporting on \\
\hline 15 & Friday last week - in which the woman & raped & in front of her husband by two Romanian men \\
\hline 16 & the unsolved case of a 30 -year-old woman & raped & in her home by a masked man who tied her up \\
\hline 17 & , 63, admitted in 2003 that she & raped & more than once when she was younger but did \\
\hline 18 & of "black dog" and "slave". I & raped & repeatedly. Eventually, I was told that the \\
\hline 19 & that they have been raped. There & raped & seven times but she won't tell," said Chipow \\
\hline 20 & so without feeling." Asked if she & raped & she replied: "I was, yes. A couple of times. \\
\hline 21 & sat on basins because since they' & raped & they hadn't stopped bleeding. I also saw \\
\hline 22 & party's own militia, who & raped & to cow them into submission and forced to \\
\hline 23 & investigated after a schoolgirl & raped & twice by a mental health patient hours after \\
\hline 24 & have been gang - & raped & , one of them by 10 men, '' said Rahab Ngugi, \\
\hline 25 & Almost every woman here & raped & , some countless times. Some have been so bad \\
\hline 26 & were tortured. Some of the women & raped & , whipped and urinated on. Others had their \\
\hline 27 & have died, and 200,000 women & raped & . "In the little village that I went to," say \\
\hline 28 & understates it. She was & raped & - Her terrible injuries left doctors convince \\
\hline 29 & bore seven children & raped & - Three were sent upstairs where they were "a \\
\hline 30 & of the case of two women & raped & and made pregnant 19 times by their tyrannical \\
\hline
\end{tabular}

In Table 10 (in bold), all lines (apart from 7, 8, 12, and 13) explicitly mention those that could be considered the most violent and sensationalistic details of rape crimes (e.g. serial rapes, gang-rapes, incest, war rapes). These are reported through adverbs or temporal phrases (e.g. repeatedly, systematically, twice, countless time), pre-modifiers (e.g. date- 
raped, gang-raped) and numerals that indicate the number of men who raped the woman/women (e.g. by two men, by five men). There are also gruesome details on how the rape was perpetrated (e.g. paraded half naked, orally raped, in front of her husband, tied her up, whipped and urinated on), and on the weapons used to perpetrate the rape (e.g. she was raped at gunpoint, raped at knifepoint). It could be argued that the inclusion of such details is unnecessary and that they are provided because they can generate strong emotions, thus increasing the newsworthiness of a story (van Dijk 1988:85).

Additionally, Table 7 (lines 1, 2, 9, 11, 12, 15, 19, 26, 29) and Table 10 (lines 3, 7, 16, $17,19,23)$ reveal that survivors are often identified in terms of their age. This is further explored in another group of randomly-selected concordance lines (Table 11).

Table 11: 30 randomly selected concordance lines of raped

\begin{tabular}{|c|c|c|c|}
\hline 1 & knives, machetes or guns, or who had been & raped & . \\
\hline 2 & eight years' jail Edinburgh. A teenager who & raped & a 47 -year-old mother while on bail awaiting \\
\hline 3 & raped mother-to-be A TEENAGER beat and & raped & a pregnant woman the day after he was allowe \\
\hline 4 & > Sally Anne suspect & raped & a Thai student' A picture of alleged killed \\
\hline 5 & the prosecution to spare his two daughters - & raped & and abused for more than 25 years - the \\
\hline 6 & women in the trade who have been stabbed, & raped & and beaten. He tells Julie Bindel why they \\
\hline 7 & reasons, said she was convinced she would be & raped & and feared for her life. The woman said the \\
\hline 8 & EF *The mother of Scarlett Keeling, who was & raped & and murdered in Goa, said she wanted further \\
\hline 9 & of Scarlett Keeling, the 15-year-old girl & raped & and murdered in Goa, was due to appear befor \\
\hline 10 & daughter's battered body to prove that she was & raped & and murdered. Scarlett's semi-clad body was \\
\hline 11 & she travelled to a nearby state. Keeling was & raped & and murdered. Two men are being held in \\
\hline 12 & attacks in which women and girls were serially & raped & and the men killed. Health clinics in the \\
\hline 13 & investigate the allegation - that a woman was & raped & and/or sexually assaulted by four players - \\
\hline 14 & times on her doorstep A teenage model was. & raped & as she lay dead or dying after being stabbed \\
\hline 15 & From four onwards she was beaten and & raped & by her stepfather, who was "a pillar of the \\
\hline 16 & 'Taxi' woman raped A 26-year-old woman was & raped & by the driver of what she thought was a \\
\hline 17 & of 32 he broke into the flat of a nurse and & raped & her at knifepoint. In her report Kastner \\
\hline 18 & cannot be named, had told colleagues Hunt had & raped & her in July 1995, but had originally not wan \\
\hline 19 & her clothes removed and that the intruder had & raped & her, she told the old Bailey. The prosecution \\
\hline 20 & the town of Amstetten, where he repeatedly & raped & her. The first Austrian to be tried for slavery \\
\hline 21 & over failure to expel charismatic healer who & raped & his patients The world of spiritualism is \\
\hline 22 & her twenties and had herself been date- & raped & in her late teens and twenties when she move \\
\hline 23 & worsen the position of women who have been. & raped & or suffered other violent or sexual assault. \\
\hline 24 & British attitudes often partially blaming a & raped & women for her behaviour is part of the reason \\
\hline 25 & Last week in north London, a young girl was. & raped & , and not only raped. It would appear that \\
\hline 26 & - If it was their daughters who were being. & raped & , I'm sure they would react differently." \\
\hline 27 & estimate seven out of 10 women have been & raped & . Mutilation Doctors say the onslaught \\
\hline 28 & doctor and said that she had been repeatedly & raped & - The first-year trainee teacher, who has no \\
\hline 29 & at me until I fell to the ground. . I was. & raped & . I don't know how many men raped me. Oth \\
\hline 30 & be stabbed, and was hit, spat on and orally & raped & at least 12 times as she was dragged by her \\
\hline
\end{tabular}

Women's age (Table 11, in purple), particularly their young age, is often emphasised by expressions such as young girl, schoolgirl, teenager. Moreover, old and year, as collocates of raped (Table 6) also tend to refer to the survivors' age, co-occurring almost exclusively in the expression $x$-year-old (as shown in the concordance list in Table 12 (in bold). 
Table 12: Concordance lines of raped and its collocates old and year

\begin{tabular}{|c|c|c|c|}
\hline 1 & nine children when 15 -year-old scarlett was. & raped & and killed on Feb 18. Miss Mac- Keown \\
\hline 2 & in the world. More than 52,000 women are. & raped & every year while the ANC is aiming \\
\hline 3 & , the mother of 15-year-old Scarlett Keeling, & raped & and murdered in Goa last month; all \\
\hline 4 & late 1995 but in March 1996 he attacked and & raped & a 22-year-old prostitute in Leeds. He \\
\hline 5 & looking happy. The 19-year-old girl was. & raped & in 2001 after leaving a nightclub and has \\
\hline 6 & yesterday. The 56-year-old man repeatedly & raped & the sisters over more than a quarter \\
\hline 7 & at knifepoint, then eight days later he & raped & another 17-year-old, again using a knife. \\
\hline 8 & . In May that year, he battered and & raped & a 22-year-old mother whom he ambushed \\
\hline 9 & The mother of a British 15-year-old & raped & and murdered in the Indian seaside state \\
\hline 10 & heartless and contemptible man who abducted and & raped & an attractive 17 -year-old girl . . . and the \\
\hline 11 & ordered yesterday that seven teenagers who gang & raped & a 14-year-old girl in a brutal " \\
\hline 12 & away, a 14-year-old girl was allegedly & raped & twice. Harkin appeared before magistrates i \\
\hline 13 & that a 26-year-old woman had been. & raped & . Evans, who has won nine caps for \\
\hline 14 & allegations that a 15 -year-old girl was. & raped & in a Birmingham secondary school. The boys, \\
\hline 15 & , 11 years ago, a 16 -year-old girl was. & raped & on parkland in Halton, Leeds. The girl \\
\hline 16 & to the 14-year-old girl who was. & raped & twice at knifepoint by Darren Harkin last \\
\hline 17 & that a 10-year-old girl had been. & raped & so violently "as to cause the child \\
\hline 18 & -AND-A-HALF years after he kidnapped, & raped & and murdered 17-year-old Hannah Foster, Manin \\
\hline 19 & heartless and contemptible man who abducted and & raped & an attractive 17 -year-old girl with everythin \\
\hline 20 & of Scarlett Keeling, the 15-year-old girl & raped & and murdered in Goa, was due to \\
\hline 21 & *The mother of a 15-year-old girl & raped & and murdered in Goa has arrived in \\
\hline 22 & military. A 52-year-old Dutch woman was & raped & and beaten on Friday night on the \\
\hline 23 & for attack on schoolgirl, 16 A man who & raped & a 16-year-old schoolgirl while on the \\
\hline 24 & after the case of an inmate who & raped & a 16-year-old girl while he was \\
\hline 25 & and said that she had been repeatedly & raped & . The first-year trainee teacher, who has \\
\hline 26 & psychiatric hospital of a patient who allegedly & raped & a 14-year-old girl. Darren Harkin, 20, absc \\
\hline 27 & case of Robert Foye, the prisoner who & raped & a 16-year-old girl after absconding from \\
\hline 28 & who absconded from an open prison and & raped & a 16 year-old girl took a new \\
\hline 29 & daughter when she was 10 years old and & raped & her when she was 17 was jailed yesterday. \\
\hline 30 & unsolved case of a 30-year-old woman & raped & in her home by a masked man \\
\hline 31 & which a 16-year-old schoolgirl was allegedly & raped & and doused with acid in Tottenham, North \\
\hline 32 & $>\quad B O y, 14$, & raped & girl, 10 A 14 -year-old boy has admitted \\
\hline 33 & 'Taxi' woman & raped & A 26-year-old woman was raped by \\
\hline 34 & ' woman raped A 26-year-old woman was & raped & by the driver of what she thought \\
\hline 35 & eight years' jail Edinburgh. A teenager who & raped & a 47-year-old mother while on bail \\
\hline 36 & , East London, on 30 April last year and & raped. & \\
\hline
\end{tabular}

Table 12 shows an overlexicalisation (Teo 2000:20) of terms emphasising youth (in most cases, the reported age is below 26, with emphasis on teenagers) in the RAPE corpus and, possibly, a focus on rapes committed against young women or on reporting the age of particularly women to signal (that this is considered) an aggravating factor.

Finally, the randomly-selected samples of concordance lines illustrated so far highlight two additional patterns, the first of which is the co-occurrence of raped with a form of the verb $B E$ (is, are, been, was, were, being - underlined in Table 7, 10, 11 and 11) as part of a passive construction. In some cases, the agent is deleted and the verb is truncated (without a by phrase); in other instances, the agent is backgrounded (e.g. by the driver, by a man, by two men). In a few cases, the action is expressed through a participle clause that provides information about the survivor but not about the perpetrator (e.g. Scarlett 
Keeling, raped and murdered in Goa - line 3, Table 12) or through a participle adjective (e.g. raped women - line 24, Table 11), which presents the rape as an attribute of the woman's identity. As with nominalisation, the transformation of an action (to rape) into a passive process obscures the agent; while this may due to the fact that, in some cases, the perpetrator is unknown (although the active voice - e.g. he raped her-could be used), at the same time, this grammatical structure casts the sentence object in a primary causal role, thus directing emphasis towards the affected rather than towards the agent.

The second pattern (in italics in Table 7, 10, 11 and 12) is the collectivisation of perpetrators (e.g. militia, crowd of teenagers) or the reference to either through personal pronouns (e.g. he, they) or generic terms (e.g. man, boy, patient, inmate). Their first names are rarely used. While this shows that generic terms were indeed used to refer to perpetrators, in most cases, the passive voice was preferred, usually with agent deletion or agent backgrounding.

To further investigate the ways in which perpetrators were referred to in the RAPE corpus, an additional set of 30 concordance lines was produced (Table 13). Cases of raped used in the passive forms were excluded to focus onto the syntactical foregrounding through the active form (for ease of presentation, patterns that have already been discussed above have not been highlighted in Table 13). 
Table 13: 30 randomly selected concordance lines of raped (active form)

\begin{tabular}{|c|c|c|c|}
\hline 1 & psychiatric hospital of a patient who allegedly & raped & a 14-year-old girl. Darren Harkin, 20, abscond \\
\hline 2 & prisoner who absconded from an open prison and & raped & a 16 year-old girl took a new twist yesterday \\
\hline 3 & on the case of Robert Foye, the prisoner who & raped & a 16-year-old girl after absconding from \\
\hline 4 & for attack on schoolgirl, 16 A man who & raped & a 16-year-old schoolgirl while on the run from \\
\hline 5 & She was right. Her son, Robert Napper, had & raped & a woman - the first of an estimated 106 sexual \\
\hline 6 & a tree on Wimbledon Common in July 1992. He & raped & again in 1992 and attempted two more rapes, \\
\hline 7 & and contemptible man who abducted and & raped & an attractive 17 -year-old girl with everything \\
\hline 8 & ever, lay a cold-blooded sexual predator who & raped & and killed victims with the help of his wife \\
\hline 9 & $>$ The evil stranger who & raped & and murdered my Hannah should die in jail, \\
\hline 10 & Kohli drove Hannah to a remote location and & raped & and strangled her before dumping her body. \\
\hline 11 & was done, and nine months later the same man & raped & another escort girl. The police decided to \\
\hline 12 & her in his van, he found somewhere quiet, he & raped & her, he then strangled her and he dumped her \\
\hline 13 & night after it insisted that a prisoner who & raped & a schoolgirl after absconding from an open $p$ \\
\hline 14 & sent to Broadmoor A mentally ill man who & raped & a schoolgirl after escaping from a low-security \\
\hline 15 & her unconscious with the chloroform, or & raped & her. Lucie's mother, Jane Steare, yesterday \\
\hline 16 & Chepstow, Monmouthshire, at knifepoint and & raped & her. Harkin, who suffers from autistic \\
\hline 17 & in his van. He found somewhere quiet and he & raped & her. He then strangled her and dumped her \\
\hline 18 & sex acts, refusing to wear a condom as he & raped & her. When officers arrived McKay refused to \\
\hline 19 & away and, in front of these witnesses, & raped & her." Dilawar has a sheaf of legal papers, \\
\hline 20 & her. I took her to a deserted place and & raped & her." A month later he retracted the confess \\
\hline 21 & office. They "took me into an empty van and & raped & me", she says. "I didn't know what they were \\
\hline 22 & at knifepoint, then eight days later he & raped & another 17-year-old, again using a knife. I \\
\hline 23 & the robber made the wife go to the bed. " He & raped & me. All the time I was concerned that my husb \\
\hline 24 & sychiatric patient who escaped from hospital and & raped & a teenage girl had been taken to see violent \\
\hline 25 & his daughter in a cellar for 24 years and & raped & her repeatedly, was an "extreme pervert"' \\
\hline 26 & During that time he beat his daughter, & raped & her repeatedly and, over the years, fathered \\
\hline 27 & , found a quiet place to park his van and & raped & the teenager. His DNA was recovered from \\
\hline 28 & inside with machetes and clubs, the youths & raped & them in front of their husbands, some of who \\
\hline 29 & barrels into the women's vaginas after they've & raped & them. I saw women who were permanently sat \\
\hline 30 & and I was taken by the rebels. Five of them & raped & me. I still have pain in my legs because the \\
\hline
\end{tabular}

Rapists seem to be described in ways that underline their "abnormality" (e.g. with references to their criminal records - prisoner - or mental illness, Table 13, in italics $)^{27}$, a pattern already observed above (e.g. Table 11, where perpetrators are referred to as coldblooded sexual predator, evil, and extreme pervert and tyrannical). Perpetrators are also referred to as stranger and robber, thus suggesting that they were not known to the woman (or intruder, line 19, Table 11, burglars and masked man lines 7 and 16, Table $10)$.

The lexical reiteration and patterning found in the concordance lines of raped showed an emphasis on extremely violent rape cases perpetrated by deviant individuals. At the same time, other forms of rape were often excluded. In fact, husbands, boyfriends, friends or colleagues were never presented as perpetrators. 


\section{Discussion}

The analysis of the most frequent collocates of rape and raped revealed that the representation of rape in the $R A P E$ corpus is characterised by a limited number of repeatedly deployed images. For example, the analysis of allegation/s of rape and rape allegation/s showed that these are often used in a context of denial and impersonality and that they tend to be combined with the reporting of violence perpetrated by celebrities or politicians. It could be argued that, since politicians or celebrities are those who, generally, may be more financially ready to pursue legal actions, the frequent use of terms surrounded by denial allows newspapers to report sensationalist stories (including the perpetrator's name, although not in the active voice) while, at the same time, limiting the risk of libel lawsuits. Admittedly, even though in the RAPE corpus there appears to be an overall absence of male agency, as shown by the frequent use of the passive voice and nominalisation, perpetrators are mentioned exceptionally often when they are public figures; however, this happens in a context permeated by the denial of the claims. It may be further argued that the strong connection between allegation $(s)$ and such cases, combined with the weaker connection between alleged (a term that does not have the same aura of denial) and rapes perpetrated by public figures, reinforces the hypothesis that special caution was exercised to report cases involving politicians or celebrities.

The caution to allocate responsibility through the obscuration of the perpetrator in the $R A P E$ corpus, particularly celebrities and politicians, is in stark contrast with the fact that the press is known for sometimes confidently allocating blame without evidence (Richardson, 2007: 129-130). It may be speculated that this caution is part of a strategy used by these newspapers not to imply that a rape happened; together with the tendency found in the RAPE corpus to i) weaken the relationship of causality between the perpetrator and the survivor and ii) not use allegation $(s)$ in relation to crimes that involve visible, physical violence, such caution may indicate that the articles analysed here reflect (and, arguably, reinforce) the public perception that false rape allegations are common ${ }^{28}$ and that, therefore, rape complaints should be treated with scepticism. This includes the idea that women may falsely report rape for money, fame and/or revenge and that they are more likely to do so if the perpetrator is a rich man. By relying on a strong denial pattern and impersonal style to distance itself from the words of the survivor, these articles may reinforce the idea that such cases should be handled with caution and that rape survivors' stories should be met with disbelief. However, the idea that women often "cry rape" is based on a misconception. In fact, in 2012, a study conducted by the Crown Prosecution Service in the UK showed that only 0.6 percent of all prosecutions for rape were based on false allegations. ${ }^{29}$

To attribute the frequent use of allegation(s) and the resulting aura of denial to a mere choice of newspapers and journalists would be simplistic. While a degree of journalistic freedom certainly exists, other factors, such as the heavy reliance on institutional sources must be considered too. In fact, the analysis showed that terms from the legal domain are 
often used in relation to rape crimes. Thus, the use of allegation(s) and alleged could be both a reflection of the legal language used to describe way sexualised violence, and a choice to reproduce such discourse and, with it, the ideology of a dominant group.

In this scenario, the lack of attention paid to perpetrators would be both a cause and a consequence of established professional traditions and social attitudes towards rape that are reinforced by these practices. Despite the inability of the press to reveal victims' names, which, in functional terms, could be considered as the equivalent of not knowing the identity of the perpetrator, there seems to be much more attention towards the former than the latter. The lack of a conventional expression such as rape perpetrator (in stark contrast with the conventional rape victim), the absence of an established noun to refer to an unknown or suspect perpetrator (e.g. attacker, rapist, offender or aggressor) as collocate of rape and raped, together with the frequent use of passive voice and nominalisation with agent deletion, suggest that perpetrators are often simply invisible and excluded from the story. This is in line with the propensity that has been found in news reports on rape crimes and during rape trials (Ehrlich 2001; Waterhouse-Watson 2013) to talk about rape as an agentless crime against women in which the responsibility of the perpetrator is obscured. It could be argued that this deletion is caused by and, at the same time, fuels the notion that rape is a 'women's problem' (Scully 1990); in addition to causing a shift of focus from perpetrators to survivors, thus potentially leading to victim blaming, it also excludes men from the discourse of the causes and solutions to male violence against women (Anderson and Doherty 2008).

Finally, the analysis has shown that when perpetrators are mentioned these tend to be strangers and/or deviant individuals. Like rapes perpetrated by public figures or associated with other violent crimes or rapes perpetrated against young women, though, these are the most exceptional, and therefore sensationalistic, cases that do not reflect the experience of rape. In fact, statistics ${ }^{30}$ show that around $90 \%$ of rapes are committed by people known to the woman, that non-consensual intercourse does not always leave visible signs of violence on the body and that women of all ages are raped. It could be argued that by prioritising sensationalism, these articles produced a distorted understanding of rape that reproduces and reinforces existing myths, suggesting that the rape of normal, ordinary women by normal, ordinary men does not exist.

Acknowledging that the representation of sexualised violence is socially constructed rather than pre-given and monolithic, allowed to identify the discursive representations and the social structures that underpin it in the RAPE corpus and to highlight the dialectical relationship between the two. As a social practice, the representation of sexist violence can be challenged and re-constructed. It does not need to be confined within rigid boundaries of its socially accepted definition, but it can become a shifting practice that is renegotiated on the basis of contextual elements. In doing so, it is not only possible to unveil the power relations and interests supported by certain constructions and definitions, but it is also possible to bring about change. By emphasising the dialectical 
relationship between the discourse surrounding sexist violence and the social structures that determine it, it is possible to challenge said discourses and structures, starting from the language we use to talk about survivors and perpetrators.

\section{References}

Anderson, I. and Doherty, K. (2008) Accounting for rape. London: Routledge.

Baker, P. (2006) Using Corpora in Discourse Analysis. London: Continuum.

Baker, P., Gabrielatos, C., Khosravinik, M., Krzyzanowski, M., McEnery, T. and Wodak, R. (2008) A useful methodological synergy? Combining Critical Discourse Analysis and Corpus Linguistics to examine discourses of refugees and asylum seekers in the UK press. Discourse and Society 19(3): 273-306.

Baroni, M. (2009) Distributions in Text. In A. Lüdeling and M. Kytö (eds) Corpus Linguistics: An International Handbook 803-821. Berlin: Mouton de Gruyter.

Bednarek, M. and Caple, H. (2012) News Discourse. London: Continuum.

Benedict, H. (1992) Virgin or Vamp: How the Press Covers Sex Crimes. New York: Oxford University Press.

Clark, K. (1992) The Linguistics of Blame. Representations of Women in The Sun's Reporting of Crimes of Sexual Violence. In M. J. Toolan (ed.) Language, Text and Context 183-197. London: Routledge.

Ehrlich, S. (2001) Representing Rape. Language and Sexual Consent. London: Routledge Emmers-Sommer, T. M., Pauley, P., Hanzal, A. and Triplett, L. (2006) Love, suspense, sex, and violence: Men's and women's film predilections, exposure to sexually violent media, and their relationship to rape myth acceptance. Sex Roles 55(6): 311-320.

Fairclough, N. (1989) Language and Power. London: Longman.

Fairclough, N. (1992) Discourse and Social Change. Cambridge: Polity Press.

Fairclough, N. (1995) Media Discourse. London: Edward Arnold.

Fairclough, N. (2003) Analysing Discourse. Textual Analysis for Social Research. London: Routledge.

Franiuk, R., Seefelt, J., Cepress, S. and Vandello, J. (2008) Prevalence and effects of rape myths in print journalism. Violence against Women 13(3): 287-309.

Grauerholz, E. (1994) Gender Socialization and Communication: The Inscription of Sexual Harassment in Social Life. In S. G. Bingham (ed.) Conceptualizing Sexual Harassment as Discursive Practice 33-44. Westport, Conn: Praeger.

Javaid, A. (2016) Feminism, masculinity and male rape: bringing male rape 'out of the closet'. Journal of Gender Studies 25(3): 283-293.

Kelly, L. (1988) Surviving Sexual Violence. Cambridge: Polity Press. 
Kitzinger, C. and Thomas, A. (1995) Sexual Harassment: A Discursive Approach. In S. Wilkinson and C. Kitzinger (eds) Feminism and Discourse: Psychological Perspectives 32-48. London: Sage.

Kress, G. and Hodge, B. (1979) Language as Ideology. London: Routledge and Kegan Paul.

Henley, N. M., Miller, M. and Beazley, J. A. (1995) Syntax, semantics, and sexual violence agency and the passive voice. Journal of Language and Social Psychology 14(1): 60-84.

Levenson, J. S. and D'Amora, D. A. (2007) Social policies designed to prevent sexual violence: The emperor's new clothes? Criminal Justice Policy Review 18(2): 168-199.

Lombard, N. and McMillan, L. (2013) Taking stock: theory and violence against women. In N. Lombard and M. Lesley (eds) Violence against Women: Current Theory and Practice in Domestic Abuse, Sexual Violence and Exploitation 233-344. London: Jessica Kingsley Publisher.

Lombard, N. (2015) Young People's Understanding of Men's Violence towards Women. Surrey: Ashgate.

Louw, B. (1993) Irony in the Text or Insincerity in the Writer? - The Diagnostic Potential of Semantic Prosodies. In M. Baker M, G. Francis and E. Tognini-Bonelli (eds) Text and Technology: In Honour of John Sinclair 157-176. Amsterdam: Benjamins.

Mason, P. and Monckton-Smith, J. (2008) Conflation, collocation and confusion: British press coverage of the sexual murder of women. Journalism 9(6): 691-710

Meyers, M. (1997) News Coverage of Violence Against Women: Engendering Blame. London: Sage.

O'Hara, S. (2012) Monsters, playboys, virgins and whores: Rape myths in the news media's coverage of sexual violence. Language and Literature 21(3): 247-259.

Pharr, S. (1991) Redefining hate violence. Transformations, Little Rock, ARK: Women's project 6(2): 1-10.

Pharr, S. (1997) Homophobia: A Weapon of Sexism. Berkeley: Chardon Press.

Potts, A., Bednarek, M. and Caple, H. (2015). How can computer-based methods help researchers to investigate news values in large datasets? A corpus linguistic study of the construction of newsworthiness in the reporting on Hurricane Katrina. Discourse \& Communication 9(2): 149-172.

Richardson, D. and Robinson, V. (2007) Introducing Gender and Women's Studies. Basingstoke: Palgrave MacMillan.

Richardson, J. (2007) Analysing Newspapers. An Approach from Critical Discourse Analysis. New York: Palgrave MacMillan.

Scully, D. (1990) Understanding sexual violence: a study of convicted rapists. New York: Routledge.

Sinclair, J. (1991) Corpus, Concordance, Collocation. Oxford: Oxford University Press. 
Sinclair, J. (1999) A Way with Common Words. In B. Hasselgard and S. Oksefjell (eds) Out of Corpora. Studies in Honour of Stig Johansson 157-179. Amsterdam: Rodopi.

Soothill, K. and Walby, S. (1991) Sex Crime in the News. London: Routledge.

Stubbs, M. (1996) Text and Corpus Analysis. Oxford: Blackwell.

Sunderland, J. (2004) Gendered Discourses. London: Palgrave MacMillan.

Teo, P. (2000) Racism in the news: A critical discourse analysis of news reporting in two Australian newspapers. Discourse and Society 11: 17-49.

Thompson, J. B. (1990) Ideology and Modern Culture. Cambridge: Polity Press.

Trask, R. (1993) A Dictionary of Grammatical Terms in Linguistics. London:

Routledge.

van Dijk, T.A. (1985) Semantic Discourse Analysis. In T. A. van Dijk (ed.) Handbook of Discourse Analysis 103-136. London: Academic Press.

van Dijk, T. A. (1988) News as Discourse. Hillsdale: Lawrence Erlbaum Associates Publishers.

van Dijk, T. A. (1991) Racism and the Press. London and New York: Routledge.

van Zoonen, L. (1994) Feminist Media Studies. London: Sage.

Waterhouse-Watson, D. (2013) Athletes, Sexual Assault and 'Trials by Media'. New York: Routledge.

Wild, K., Church, A., McCarthy, D. and Burgess, J. (2013) Quantifying lexical usage: Vocabulary pertaining to ecosystems and the environment. Corpora 8(1): 53-79.

Wood, J. T. (1994) Saying it Makes it so: The Discursive Construction of Sexual Harassment. In S. G. Bingham (ed.) Conceptualizing Sexual Harassment as Discursive Practice 17-32. Westport, Conn: Praeger.

\footnotetext{
${ }^{1}$ http://www.legislation.gov.uk/ukpga/2003/42/section/1 (05 May 2017)

${ }^{2}$ https://www.gov.uk/government/uploads/system/uploads/attachment_data/file/116417/hosb1011.pdf; https://fullfact.org/crime/rape-conviction-rates-deserve-careful-explanation/

${ }^{3}$ http://www.justiceinspectorates.gov.uk/hmic/publications/rape-monitoring-group-digests-and-data-2014$15 /$ (28 May 2017)

${ }^{4}$ https://www.nexis.com (29 November 2016)

${ }^{5}$ AntConc was developed by Laurence Anthony. http://www.laurenceanthony.net/software.html (29 November 2016).

${ }^{6}$ This paper is based on an ongoing diachronic study on the representation of rape between 2008 and 2018. ${ }^{7}$ Considering the relatively small size of the $R A P E$ corpus, words were lower-cased, since 'preserving case distinctions [...] will duplicate word types' (Baroni, 2009: 805), thus reducing the number of occurrences of potentially relevant words.

${ }^{8}$ The minimum frequency of each collocate co-occurring with the node was set to 3 .

${ }^{9}$ http://bncweb.lancs.ac.uk/bncwebSignup/user/login.php (28 May 2017).

${ }^{10}$ Concordance lines were randomly selected using the RAND formula in Excel.

${ }^{11}$ This also allowed to distinguish between the simple past and the past participle of to rape.

${ }^{12} \mathrm{Co}$-occurrences of rape with grammatical words were not taken into consideration for this analysis.
} 
${ }^{13}$ In a window span of 4 words on either side of the node word.

${ }^{14}$ Rape occurs 1207 times in the RAPE corpus. It could be either a verbal and nominal form of the lemma RAPE, but it was observed that rape mostly occurred as a noun (it only occurred 42 times as a verb, mostly in the infinitive form to rape).

${ }^{15} \mathrm{http}: / /$ www.oed.com/ (9 September 2016)

${ }^{16}$ In a window span of 4 to the right and 4 to the left of the node word, sorted by T-score and with a minimum frequency of 3 occurrences.

${ }^{17}$ https://wordnet.princeton.edu/ (23 November 2016)

${ }^{18} \mathrm{http}: / /$ www.cps.gov.uk/legal/v to z/witness protection and anonymity/

${ }^{19} \mathrm{https} / / / \mathrm{www}$. parliament.uk/business/publications/research/key-issues-parliament-

2015/justice/anonymity-for-defendants/

${ }^{20}$ In some cases, the expression taken seriously is used. However, the need to specify that rape allegations are taken seriously may implicitly suggest that this is not always the case.

${ }^{21}$ This is absent in the BNCweb too.

${ }^{22}$ Except for line 25 and 29, where alleged appears as a verb.

${ }^{23}$ In total, 23 cases of allegation out of 35 and 10 out of 25 occurrences of allegations refer to celebrities or politicians.

${ }^{24}$ Raped occurred 450 in the RAPE corpus.

${ }^{25}$ The minimum frequency was set to 1 to collect all the terms that referred to criminal actions. The window span was 1 word on either side of the node word sorted in descending order of T-score.

${ }^{26}$ The minimum frequency was set to 1 . Each crime present in the RAPE corpus was searched in the General News corpus using the formula *some_crime* and or and *some_crime*.

${ }^{27}$ But also (line 24 and 26, Table 12).

${ }^{28} \mathrm{http}: / /$ www.cps.gov.uk/news/latest news/under the spotlight/ (28 November 2016)

${ }^{29}$ http://www.cps.gov.uk/publications/research/perverting_course of justice_march_2013.pdf (21 October 2016)

${ }^{30} \mathrm{http}: / /$ www.cps.gov.uk/legal/p to r $\mathrm{r} / \mathrm{rape}$ and_sexual_offences/societal_myths/;

http://cambridgerapecrisis.org.uk/rape-myths 